\title{
Genetic parameters of milk fat-to-protein ratio in first three lactations of Polish Holstein-Friesian cows
}

\author{
A. Satoła ${ }^{1}$ and E. Ptak \\ University of Agriculture in Krakow, Faculty of Animal Science, Department of Genetics and Animal Breeding \\ al. Mickiewicza 21, 31-120 Krakow, Poland
}

KEY WORDS: milk yield, urea, lactose, heritability, genetic correlation, energy balance

Received: 4 September 2018

Revised: 10 January 2019

Accepted: $\quad 7$ April 2019

${ }^{1}$ Corresponding author:

e-mail: a.satola@ur.krakow.pl

\begin{abstract}
The aim of the study was to estimate the genetic parameters of milk fat-to-protein ratio in the first three lactations of Polish Holstein-Friesian cows. Data included 104875 test-day records of 6299 cows calving from years 2000-2012. Genetic parameters were estimated with a multitrait random regression model using the Bayesian method via Gibbs sampling. The linear model for fat-to-protein ratio and milk traits (milk yield, lactose percentage, milk urea concentration) included fixed herd-test-day effect, fixed regressions within age at calving by season of calving subclasses, and random regressions for additive genetic and permanent environmental effects. All regressions were modelled using fourth-order Legendre polynomials. The average daily heritability of fat-to-protein ratio ranged from 0.24 to 0.31 . Fat-to-protein ratio was negatively genetically correlated with milk yield for almost every day in milk in each lactation, with means of $-0.52,-0.24$ and -0.05 in the first, second and third lactations, respectively. Average genetic correlations of fat-to-protein ratio with lactose percentage and milk urea concentration were rather low or close to zero $(-0.08$ to 0.10$)$ except for the genetic correlation with milk urea content in the second lactation (0.32). The results suggest that fat-to-protein ratio is a heritable trait and might be used in the selection of Polish Holstein-Friesians assuming that the relationship between fat-to-protein ratio and economically important traits will be investigated.
\end{abstract}

\section{Introduction}

In the past, genetic improvement of dairy cattle was focused on high milk production. This led to deterioration of health and fertility traits and in consequence increased veterinary treatment costs and culling rates (Butler and Smith, 1989; Oltenacu and Broom, 2010). To prevent these negative effects, new traits (conformation, fertility, survival) were consecutively incorporated into selection indices in many countries including Poland. Recently, traits connected with the energy balance of cows have drawn the in- terest of researchers. Energy balance is defined as the difference between energy intake and energy requirements for milk output and maintenance (Buttchereit et al., 2010). Negative energy balance has serious consequences for body function and in turn determines cow health and fertility. Cows with a negative energy balance are more prone to mastitis, lameness, digestive and locomotive problems and metabolic diseases such as ketosis (Goff and Horst, 1997; Heuer et al., 1999; Collard et al., 2000; Negussie et al., 2013).

Energy balance can be calculated to indicate the metabolic status of a cow, but the costs of mea- 
surement are too high to be routinely applied, so researchers have tried to find an easily measured and reliable indicator of energy balance among milk composition traits (Grieve et al., 1986; de Vries and Veerkamp, 2000; Reist et al., 2002; Friggens et al., 2007; Buttchereit et al., 2011). Fat-to-protein ratio (FPR) seems to be an appropriate indicator of energy balance status of lactating cow. In the study of Buttchereit et al. (2011) examining the genetic relationship between daily energy balance and FPR it was shown that the correlation was high at the beginning of lactation [ -0.62 at 15 day in milk (DIM)] and decreased toward zero at 180 DIM. The authors concluded that FPR could be a good indicator of energy balance during early lactation, that is, during the time of energy deficit. Cows with a negative energy balance mobilize fat from body reserves to compensate energy deficiency (Loker et al., 2012). This causes increased fat synthesis in the udder (Buttchereit et al., 2010). When feed intake in early lactation is inadequate, protein synthesis by ruminal bacteria is insufficient, resulting in decreasing protein content in milk (Negussie et al., 2013). In a situation of increasing milk fat percentage and decreasing milk protein percentage, the use of FPR as a measure of a lack of energy supply through feed seemed reasonable. Heuer et al. (1999) and Negussie et al. (2013) showed that cows with a high FPR $(>1.5)$ are more prone to ketosis, displaced abomasum, ovarian cysts, lameness and mastitis. Buttchereit et al. (2010) remarked that the decrease of FPR stopped at the same moment of lactation as the energy balance stabilized.

Milk yield and its components (e.g., fat and protein percentage) are routinely measured in Polish Holstein-Friesian cows, allowing easy calculation of FPR without any extra costs. Before including a new trait into a breeding programme, genetic parameters should be estimated. In the literature the heritability of FPR ranges from 0.11 to 0.54 (Pena, 2006; Buttchereit et al., 2011; Jamrozik and Schaeffer, 2012; Loker et al., 2012; Battagin et al., 2013; Negussie et al., 2013; Nishiura et al., 2015; Buaban et al., 2016; Puangdee et al., 2017).

The relationship of FPR with production traits, fertility traits, somatic cell score, body condition score and locomotion has been the subject of some studies (Toni et al., 2011; Jamrozik and Schaeffer, 2012; Loker et al., 2012; Battagin et al., 2013; Negussie et al., 2013; Nishiura et al., 2015; Buaban et al., 2016; Puangdee et al., 2017). Most of those authors noted negative or close to zero genetic correlations between FPR and milk yields. Jamrozik and Schaeffer (2012) and Negussie et al. (2013) found a low positive genetic correlation between FPR and somatic cell score (SCS) (up to 0.20 ) and suggested that FPR may be used as additional trait in genetic selection for resistance to clinical mastitis. The relationship of FPR with economically important but low-heritable trait such as fertility (Negussie et al., 2013; Buaban et al., 2016; Puangdee et al., 2017) opens an opportunity to use FPR in selection programmes.

In Poland during the last two decades the milk yield per cow increased significantly (from $4287 \mathrm{~kg}$ in year 1995 to $7582 \mathrm{~kg}$ in year 2014 on average) (Piechowska, 2015). As a consequence the fertility was deteriorated and health problems occurred more often, especially for high-producing cows. Those animals tended to be in a negative energy balance in the early lactation which led to metabolic diseases among which the most serious is ketosis. According to the published reports, clinical ketosis occurs in case of about $4-10 \%$ of dairy cows, whereas incidences of subclinical ketosis are observed more often, i.e. in $10-50 \%$ of cows all over the world (Geishauser et al., 2000; Zwald et al., 2004; McArt et al., 2012). In Poland about $10 \%$ of cows are at risk of ketosis, and at the beginning of first lactation this percentage rises to $30 \%$ (Kowalski et al., 2015). Researchers try to find simple indicator for ketosis, especially for subclinical ketosis, and FPR seems to be a good indicator of energy balance at the beginning of lactation and indirectly - indicator of ketosis.

Knowledge of genetic parameters of FPR gives an opportunity to construct additional subindex in the Polish selection index (PF - Production and Functional traits) and as Nishiura et al. (2015) mentioned FPR would be a useful component of index for improving an energy balance. Puangdee et al. (2017) emphasize that modern breeding programmes have driven from the excessive milk production toward health, fertility and energy balance. This trend was also visible in Polish selection index when another subindices (conformation, fertility, longevity) appeared and production subindex is only $40 \%$ of PF.

The objective of this study was to estimate heritability of FPR, genetic correlations between FPR and daily milk yield, lactose percentage and urea content in milk within the first three lactations of Polish Holstein-Friesian cows. Additionally, daily genetic correlations between FPR in the same days of different lactations were estimated. 


\section{Material and methods}

Records of test-day milk yield, fat, protein and lactose percentage, as well as milk urea concentration in the first three lactations of Polish HolsteinFriesian cows calving from years 2000 to 2012, were provided by a commercial dairy farm having nine herds. Daily FPR was calculated as the ratio of test-day fat percentage to protein percentage. Only records between 5 and 305 DIM were analysed. Cows being in second and third lactations without records available for previous lactations were excluded. After those restrictions there were 104875 test-day (TD) records of 6299 cows in the data set (50 344, 34323 and 20208 TD records from 6299 first, 4280 second and 2622 third lactations, respectively). Cows were daughters of 637 sires and 4556 dams. There were 2711 dams with their own records in the data file. Cows with records and their parents were included in the pedigree file, which contained 8781 animals in total.

Within each of the first three lactations, fourtrait (milk yield, FPR, lactose percentage, milk urea content) analyses were performed to estimate genetic parameters. Additionally, three two-trait analyses were conducted to estimate genetic correlations of FPR between the same days of different parities (1 and 2, 1 and 3, 2 and 3).

Two seasons of calving were created: April to September and October to March. The following calving age classes (in months) were defined: $20-24,25-26,27-28,29-30,31-45$ in the first lactation; 31-38, 39-41, 42-44, 45-65 in the second lactation; and 43-51, 52-55, 56-74 in the third lactation. There were 1410, 1129 and 830 herd-testday classes (HTD) in the first, second and third lactations, respectively.

In matrix notation the model for the $m$-th trait was:

$$
y_{m}=H_{m} h_{m}+X_{m} b_{m}+Z_{m} a_{m}+W_{m} p_{m}+e_{m}
$$

where: $y_{m}-$ vector of observations, $h_{m}-$ vector of fixed herd-test-day effects, $b_{m}-$ vector of fixed regression coefficients for season of calving by age at calving effects, $a_{m}$ - vector of random regression coefficients for additive genetic effects, $p_{m}$ - vector of random regression coefficients for permanent environmental effects, $e_{m}-$ vector of residuals, $H_{m}, X_{m}, Z_{m}, W_{m}$ - incidence matrices assigning observations to effects.

Both fixed and random regressions were modelled using fourth-order Legendre polynomials (Kirkpatrick et al., 1994).
The multiple trait model for $n$ traits was as follows:

where:

$$
y=H h+X b+Z a+W p+e
$$

$$
\begin{gathered}
y=\left[y_{1}^{\prime} \ldots y_{n}^{\prime}\right]^{\prime}, h=\left[h_{1}^{\prime} \ldots h_{n}^{\prime}\right]^{\prime}, b=\left[b_{1}^{\prime} \ldots b_{n}^{\prime}\right]^{\prime}, a=\left[a_{1}^{\prime} \ldots a_{n}^{\prime}\right]^{\prime}, \\
p=\left[p_{1}^{\prime} \ldots p_{n}\right]^{\prime}, e=\left[e_{1}^{\prime} \ldots e_{n}^{\prime}\right]^{\prime}
\end{gathered}
$$

and $H, X, Z, W$ are direct sums of matrices, that is:

$$
H=\Sigma^{+} H_{m}, X=\Sigma^{+} X_{m}, Z=\Sigma^{+} Z_{m}, W=\Sigma^{+} W_{m}
$$

The (co)variance structure of the model was:

$$
\operatorname{Var}\left(\begin{array}{l}
a \\
p \\
e
\end{array}\right)=\left(\begin{array}{ccc}
A \otimes G_{0} & 0 & 0 \\
0 & I \otimes P_{0} & 0 \\
0 & 0 & R
\end{array}\right)
$$

where: $I$ - identity matrix, $A$ - additive genetic relationship matrix, $G_{0}$ and $P_{0}$ - covariance matrices for genetic and permanent environmental regression coefficients, and $R$ - diagonal residual matrix with elements on the diagonal equal to residual variances for each trait.

A Bayesian method via Gibbs sampling and the GIBBS1F90 software (Misztal, 2008) were used to estimate (co)variance components. There were 100000 samples of (co)variance components generated, with the first 10000 samples discarded as the burnin period. Estimates of (co)variances were calculated as averages of the remaining 90000 samples and then they were used to calculate heritabilities and genetic correlations (Falconer, 1989; Jamrozik and Schaeffer, 1997).

\section{Results}

\section{Descriptive statistics}

Means and standard deviations of test-day milk yield, milk components and FPR in the first three lactations of Polish Holstein-Friesian cows are shown in Table 1. Means of test-day milk yield were $26.5 \pm 7.6,30.5 \pm 10.0$ and $31.3 \pm 10.8$ in first,

\begin{tabular}{|c|c|c|c|c|c|}
\hline \multirow[t]{2}{*}{ Trait } & \multicolumn{2}{|c|}{ Lactation 1} & \multicolumn{2}{|c|}{ Lactation 2} & Lactation 3 \\
\hline & Mean & SD & Mean & SD & Mean SD \\
\hline Milk, kg & 26.5 & 7.6 & 30.5 & 10.0 & $\begin{array}{ll}31.3 & 10.8\end{array}$ \\
\hline Fat, \% & 3.87 & 0.77 & 3.89 & 0.80 & $3.90 \quad 0.84$ \\
\hline Protein, \% & 3.37 & 0.34 & 3.40 & 0.38 & $\begin{array}{ll}3.39 & 0.39\end{array}$ \\
\hline Fat-to-protein ratio & 1.15 & 0.21 & 1.15 & 0.22 & $1.16 \quad 0.24$ \\
\hline Lactose, \% & 4.92 & 0.22 & 4.82 & 0.25 & $\begin{array}{ll}4.77 & 0.27\end{array}$ \\
\hline Milk urea, mg/l & 236 & 91.1 & 232 & 93.0 & 90.6 \\
\hline
\end{tabular}
second and third lactations, respectively and means of test-day FPR were $1.15 \pm 0.21,1.15 \pm 0.22$ and $1.16 \pm 0.24$, respectively.

Table 1. Milk yield, fat-to-protein ratio, lactose percentage and milk urea content in the first three lactations, means with standard deviations (SD) 


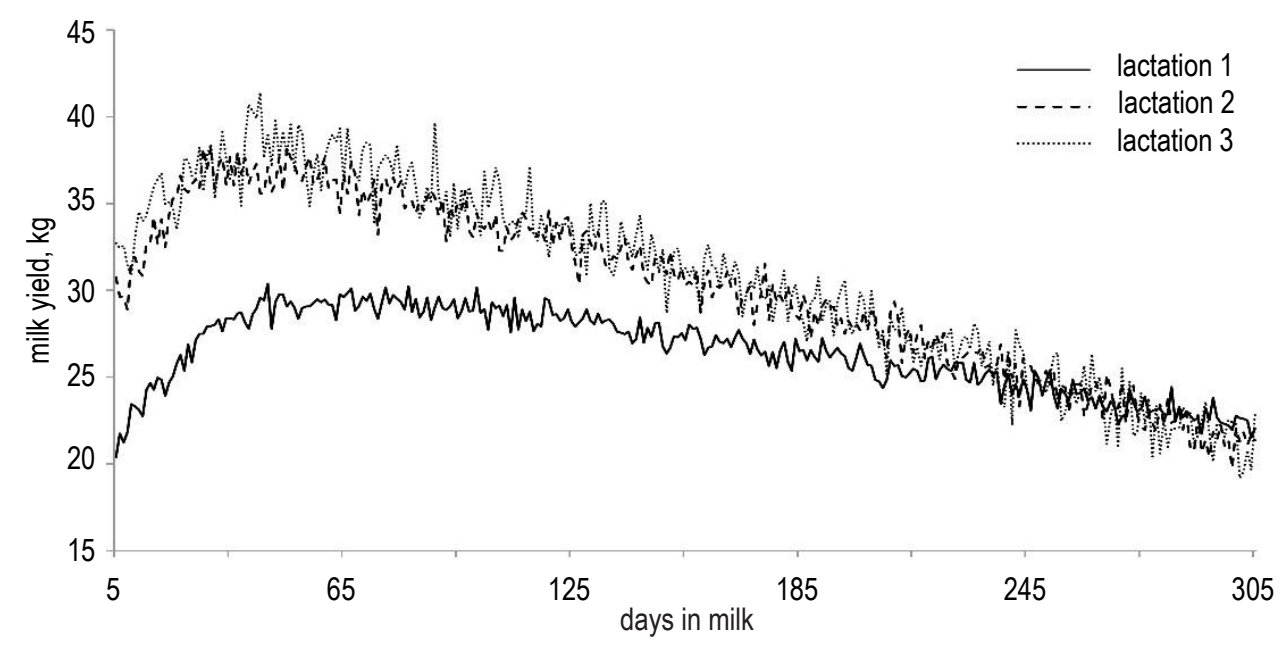

Figure 1. Average lactation curves of milk yield $(\mathrm{kg})$ in the first three lactations

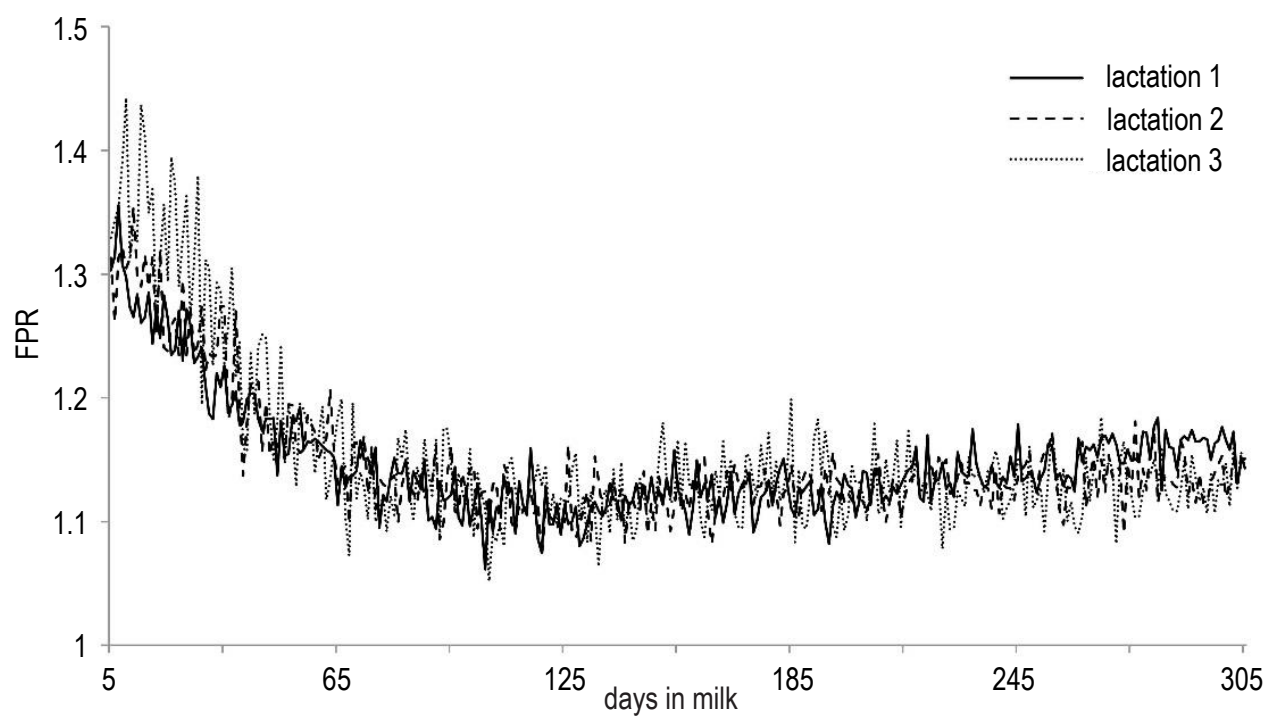

Figure 2. Average lactation curves of fat-to-protein ratio (FPR) in the first three lactations

The average curves of milk yield in the first three lactations, presented in Figure 1, are typical in shape. Milk yield increased to about 45 DIM with peak yield equalled to $30.4,38.3$ and 41.4 in first, second and third lactation, respectively. After the peak first lactation was more persistent than second and third lactations, which were very similar in shape and values.

The average curves of FPR in the first, second and third lactations are presented in Figure 2. The highest values of FPR occurred during the second week of lactation: 1.35 in 7 DIM of the first lactation, 1.35 in 11 DIM of the second lactation and 1.44 in 9 DIM of the third lactation. The decreasing tendency of FPR was observed to 65 DIM and then FPR stabilized at 1.15 to the end of 305-day lactation.

It was worth to notice that FPR stabilization at the level of 1.15 started about twenty days after the peak milk yield in each of the first three lactations of Polish Holstein-Friesians.

\section{Variances}

Figures 3, 4 and 5 show genetic, permanent environmental and residual variances for FPR in the first, second and third lactations, respectively. At the beginning of the first and third lactations the values of genetic variance were the highest ( 0.036 and 0.050 , respectively), then decreased up to 45 DIM to remain constant to the end of lactation (with values oscillated around 0.01). In the second lactation the highest value of genetic variance occurred also immediately after calving but it was much lower (0.021) and stabilized (at 0.01) earlier (i.e. from 25 DIM) than in adjacent lactations.

For each of the first three lactations permanent environmental variances were the highest at the beginning of lactation $(0.077,0.089$ and 0.135 in first, second and third lactations, respectively) and decreased rapidly during first 65 DIM for values 0.01 or lower. Up to 75 DIM these variances were 


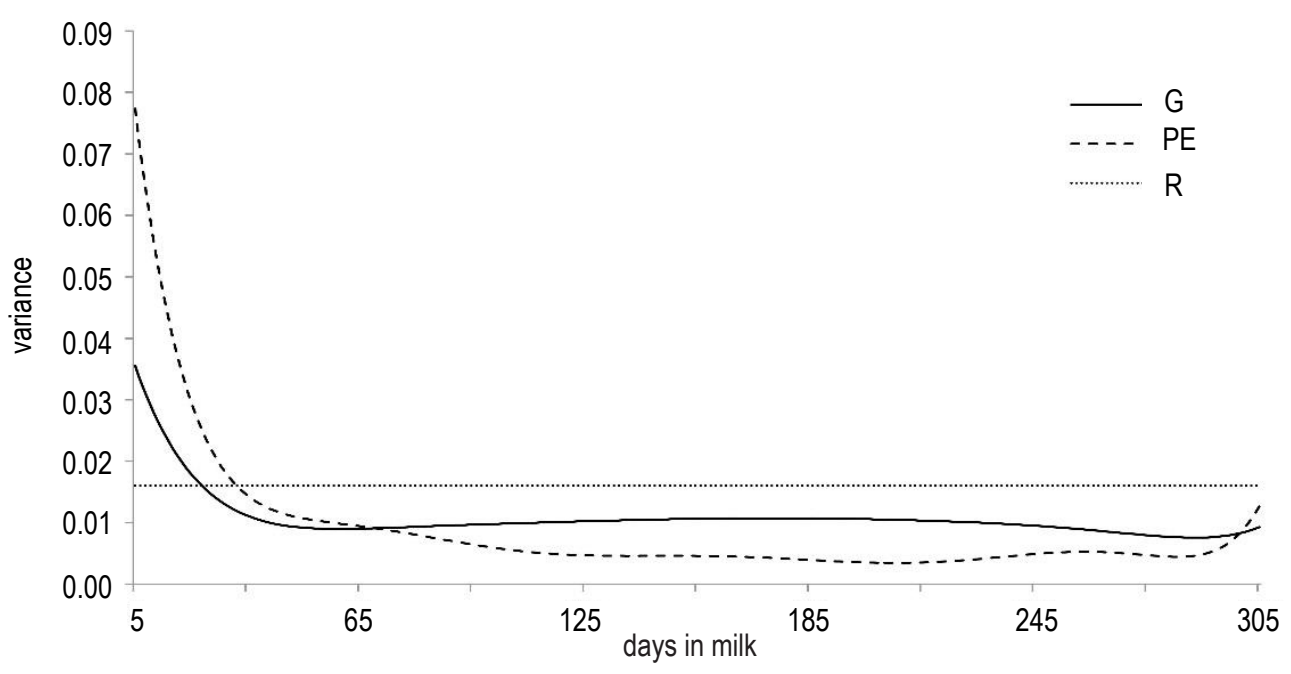

Figure 3. Genetic $(G)$, permanent environmental $(P E)$ and residual $(R)$ variances for fat-to-protein ratio in the first lactation

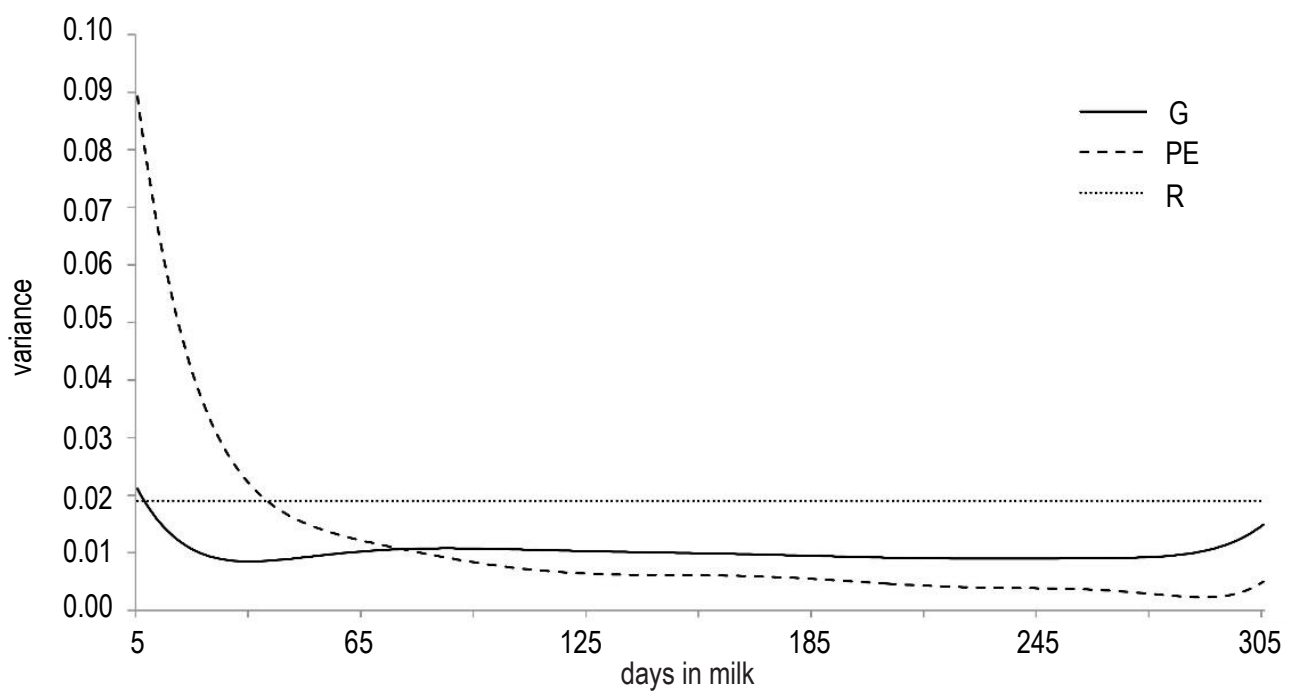

Figure 4. Genetic $(G)$, permanent environmental $(P E)$ and residual $(R)$ variances for fat-to-protein ratio in the second lactation

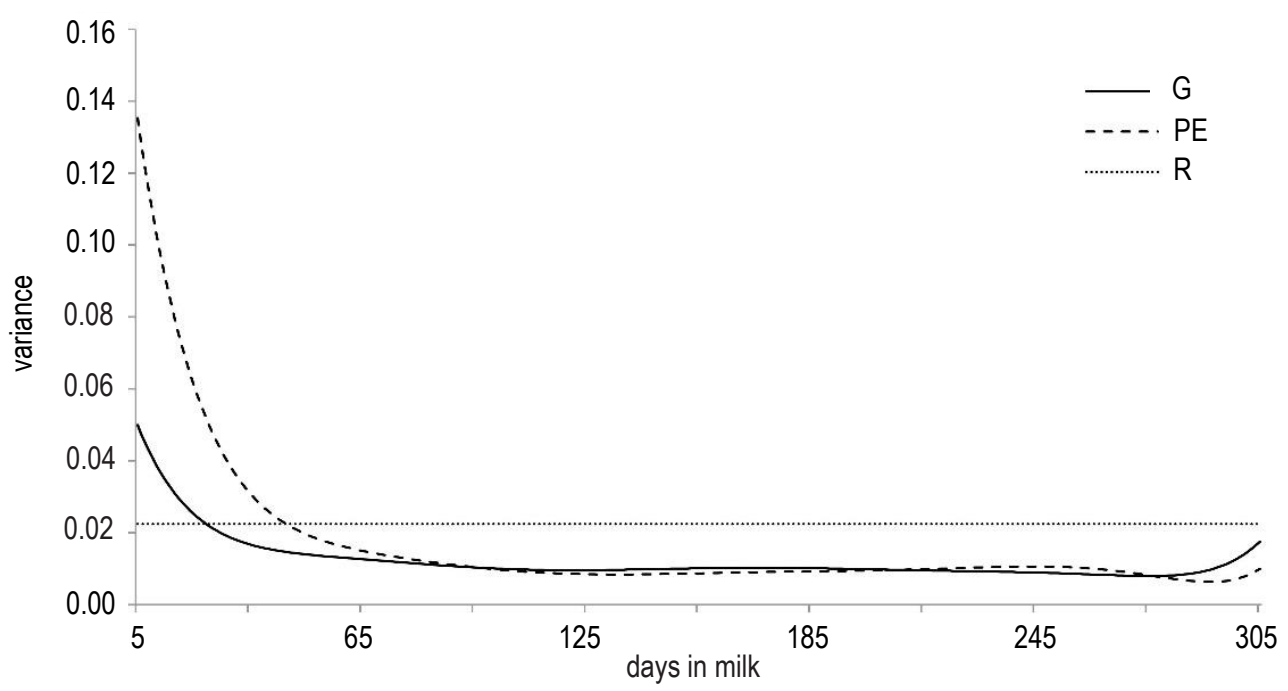

Figure 5. Genetic $(G)$, permanent environmental $(P E)$ and residual $(R)$ variances for fat-to-protein ratio in the third lactation 


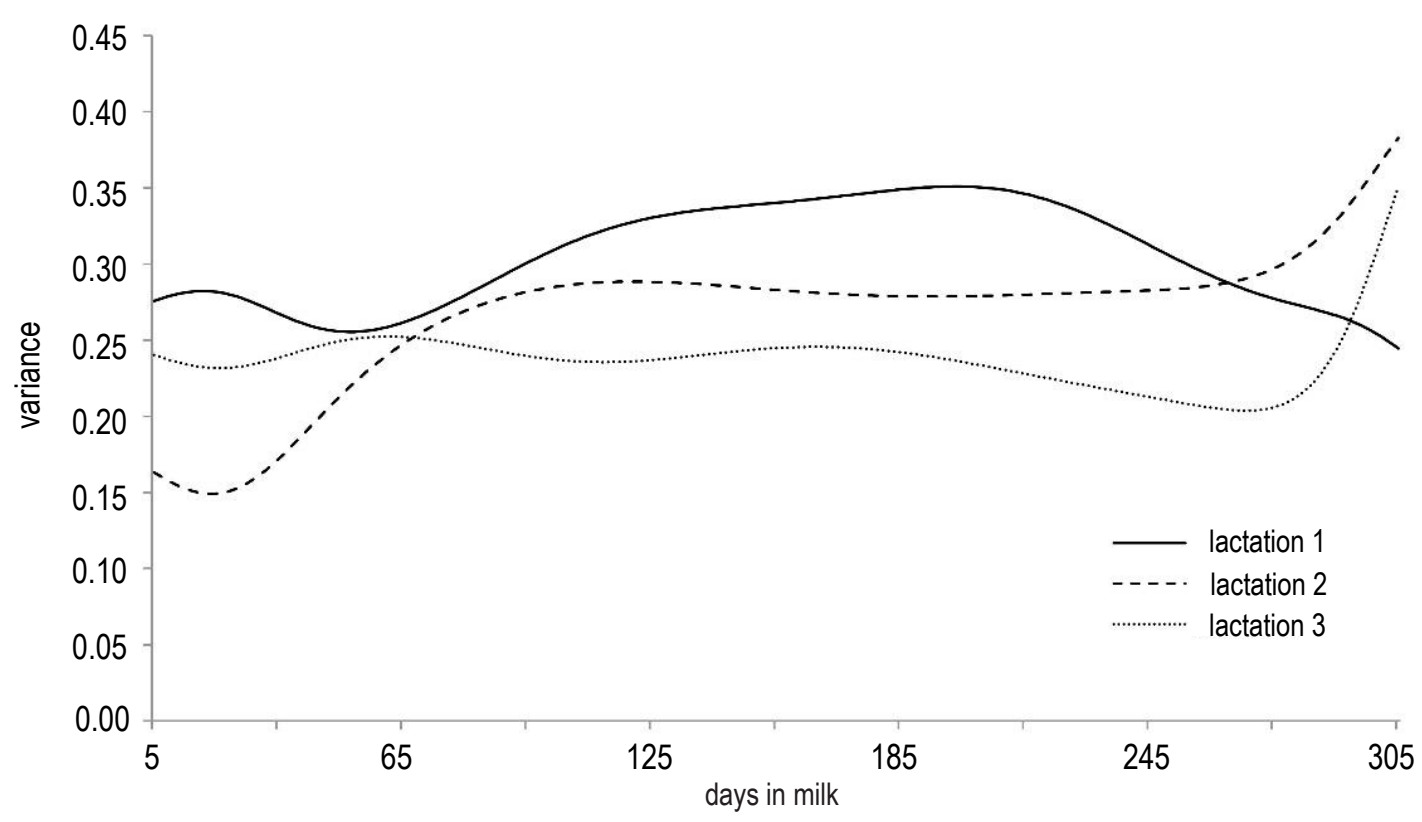

Figure 6. Daily heritabilities $\left(\mathrm{h}^{2}\right)$ of fat-to-protein ratio throughout the first three lactations

much higher than genetic variances. For the remaining part of lactations permanent environmental variances were similar or slightly lower than genetic variances.

It was assumed that residual variance for FPR was constant throughout lactation; the estimated values \pm standard deviations were $0.016 \pm 0.0050$, $0.019 \pm 0.0009$ and $0.022 \pm 0.0055$ in lactations 1 , 2 and 3 , respectively.

Residual variance was higher than genetic and permanent environmental variances for almost all DIM of the first, second and third lactations (except 5-45 DIM). This may suggest that some effects which could influence FPR were not included in the model.

Average genetic variances for FPR were quite similar in the first three lactations $(0.011,0.010$ and 0.012 in parities 1,2 and 3 , respectively), whereas average permanent environmental variance was lowest in the first lactation (0.009) and was increasing slightly with lactation number $(0.011$ in second and 0.017 in third lactation).

\section{Heritabilities}

The estimates of heritability ranged from 0.24 to 0.35 in the first lactation, from 0.15 to 0.38 in the second, and from 0.20 to 0.35 in the third; they were the highest in the first lactation except for the last 40 days in which FPR was much heritable in the second lactation (Figure 6). Heritability estimates were lower at the peripheries of the first lactation than in the middle of it. In the second lactation the heritability values were the lowest at the beginning of lactation (up to 65 DIM), oscillated around 0.27 in the middle part of it, and increased slightly during the last month. In the third lactation the heritability values were relatively constant throughout the whole lactation $(0.20-0.25)$ with exception of the end of lactation. The average heritabilities for FPR were $0.31,0.27$ and 0.24 in parities 1,2 and 3 , respectively. They were higher than the average heritabilities for milk yield $(0.20,0.19,0.12)$ and milk urea concentration $(0.22,0.19,0.19)$, and lower than average heritabilities for lactose percentage $(0.32$, $0.31,0.26)$ (Table 2).

\section{Genetic correlations}

Genetic correlations between FPR and milk yield, lactose percentage and milk urea content in the first, second and third lactation are shown in Figures 7,8 and 9 , respectively.

Genetic correlations between FPR and milk yield changed from -0.62 to -0.30 in the first lactation, from -0.39 to 0.11 in the second, and from -0.23 to 0.07 in the third, with means of -0.52 , -0.24 and -0.05 , respectively (Table 2). Generally, FPR was negatively genetically correlated with milk yield at each DIM of the first three lactations except for the first 25 days of the second lactation and 175-255 DIM of the third lactation.

The average genetic correlations between FPR and lactose percentage at successive DIM were weak $(-0.08,0.10$ and -0.06 in parities 1,2 and 3 , respectively). They ranged from -0.31 to 0.01 in the first, from -0.08 to 0.23 in the second, and from -0.39 to 0.09 in the third lactations, with the strongest relationship at the beginning of the first three lac- 
Table 2. Average daily heritabilities (on diagonal), genetic correlations (above diagonal) and permanent environmental correlations (below diagonal), with standard deviations (in parentheses), by lactation

\begin{tabular}{|c|c|c|c|c|c|}
\hline Lactation & Trait & Milk & Fat-to-protein ratio & Lactose & Milk urea \\
\hline \multirow[t]{4}{*}{1} & Milk, kg & $0.20(0.04)$ & $-0.52(0.11)$ & $0.12(0.10)$ & $0.27(0.09)$ \\
\hline & Fat-to-protein ratio & $-0.36(0.11)$ & $0.31(0.03)$ & $-0.08(0.08)$ & $0.03(0.06)$ \\
\hline & Lactose, \% & $0.55(0.05)$ & $-0.27(0.08)$ & $0.32(0.04)$ & $0.06(0.08)$ \\
\hline & Milk urea, mg/l & $0.41(0.13)$ & $0.01(0.12)$ & $0.33(0.08)$ & $0.22(0.02)$ \\
\hline \multirow[t]{4}{*}{2} & Milk, kg & $0.19(0.02)$ & $-0.24(0.12)$ & $0.28(0.17)$ & $0.17(0.06)$ \\
\hline & Fat-to-protein ratio & $-0.38(0.10)$ & $0.27(0.05)$ & $0.10(0.09)$ & $0.32(0.05)$ \\
\hline & Lactose, $\%$ & $0.60(0.06)$ & $-0.23(0.12)$ & $0.31(0.04)$ & $0.15(0.12)$ \\
\hline & Milk urea, mg/l & $0.41(0.10)$ & $-0.15(0.10)$ & $0.33(0.10)$ & $0.19(0.04)$ \\
\hline \multirow[t]{4}{*}{3} & Milk, kg & $0.12(0.02)$ & $-0.05(0.08)$ & $0.28(0.23)$ & $0.29(0.14)$ \\
\hline & Fat-to-protein ratio & $-0.36(0.04)$ & $0.24(0.02)$ & $-0.06(0.12)$ & $0.03(0.07)$ \\
\hline & Lactose, $\%$ & $0.66(0.05)$ & $-0.09(0.09)$ & $0.26(0.03)$ & $-0.04(0.19)$ \\
\hline & Milk urea, mg/l & $0.40(0.13)$ & $-0.10(0.18)$ & $0.49(0.09)$ & $0.19(0.05)$ \\
\hline
\end{tabular}

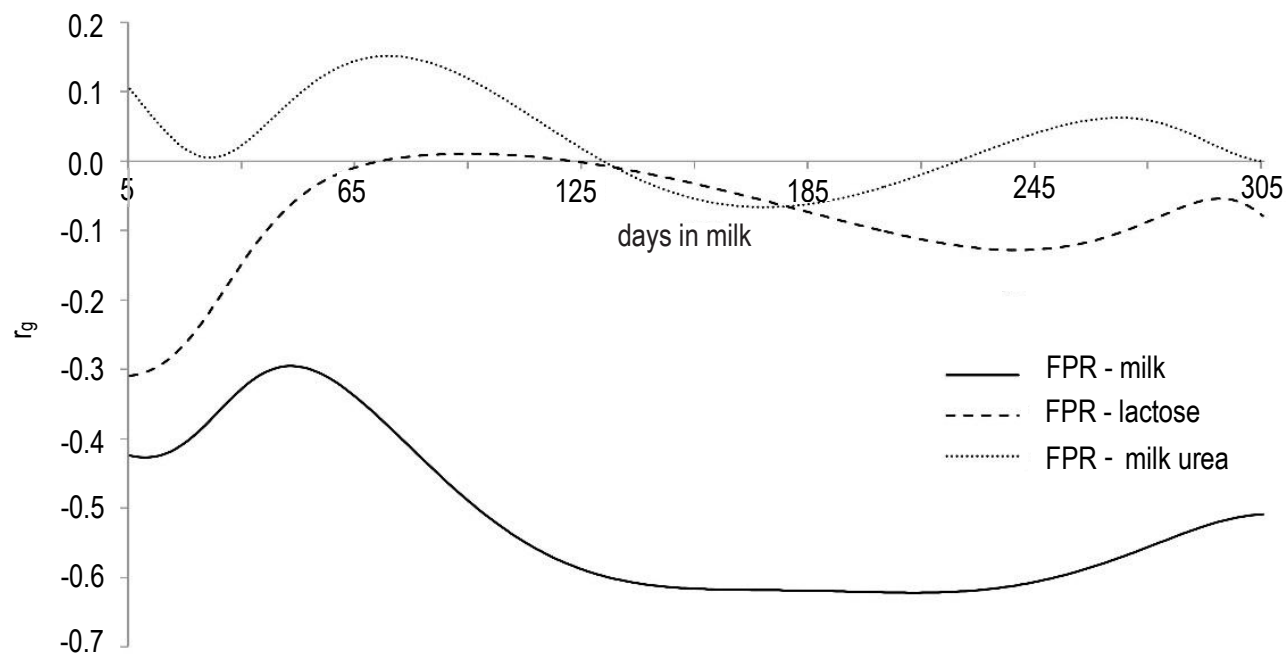

Figure 7. Genetic correlations $\left(r_{\mathrm{g}}\right)$ between fat-to-protein ratio (FPR) and milk yield, lactose percentage and milk urea content in the first lactation

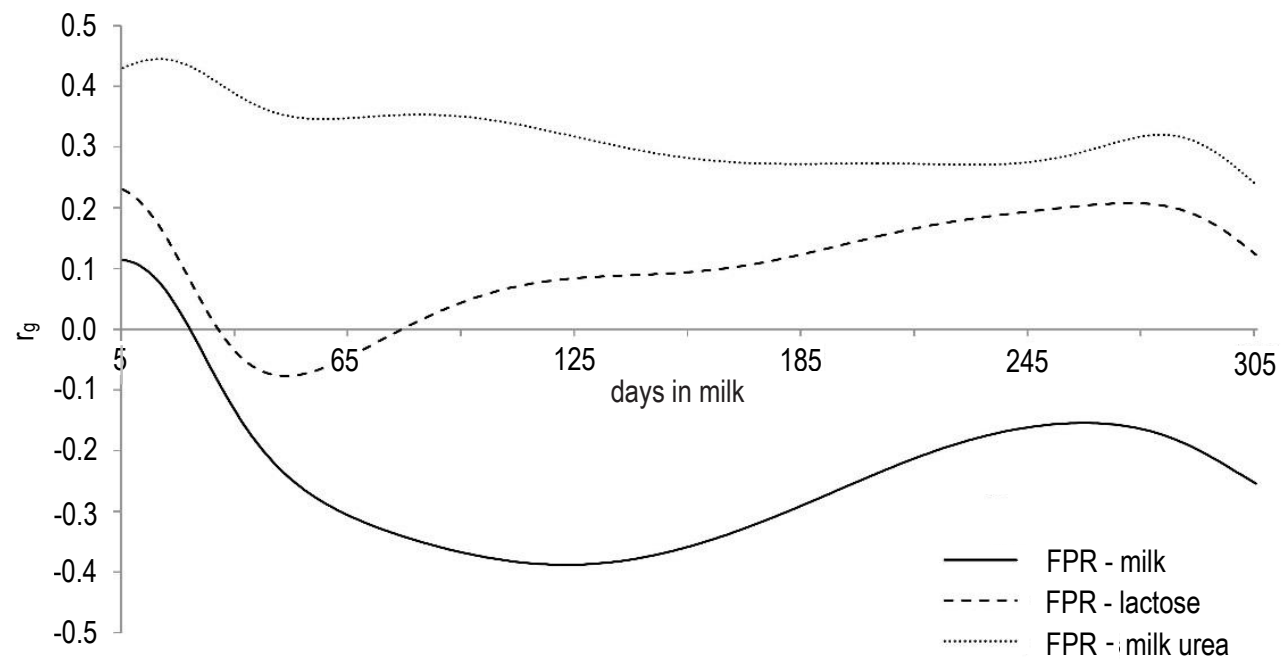

Figure 8. Genetic correlations $\left(r_{g}\right)$ between fat-to-protein ratio (FPR) and milk yield, lactose percentage and milk urea content in the second lactation 


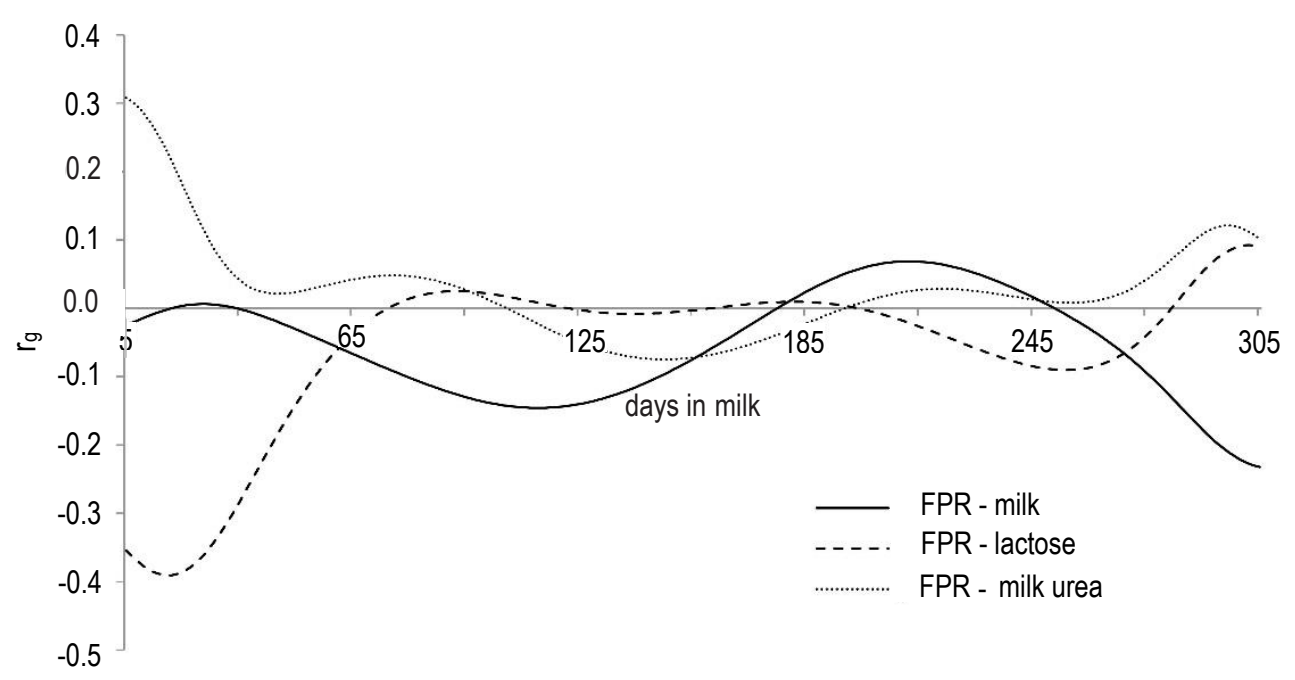

Figure 9. Genetic correlations $\left(r_{g}\right)$ between fat-to-protein ratio (FPR) and milk yield, lactose percentage and milk urea content in the third lactation

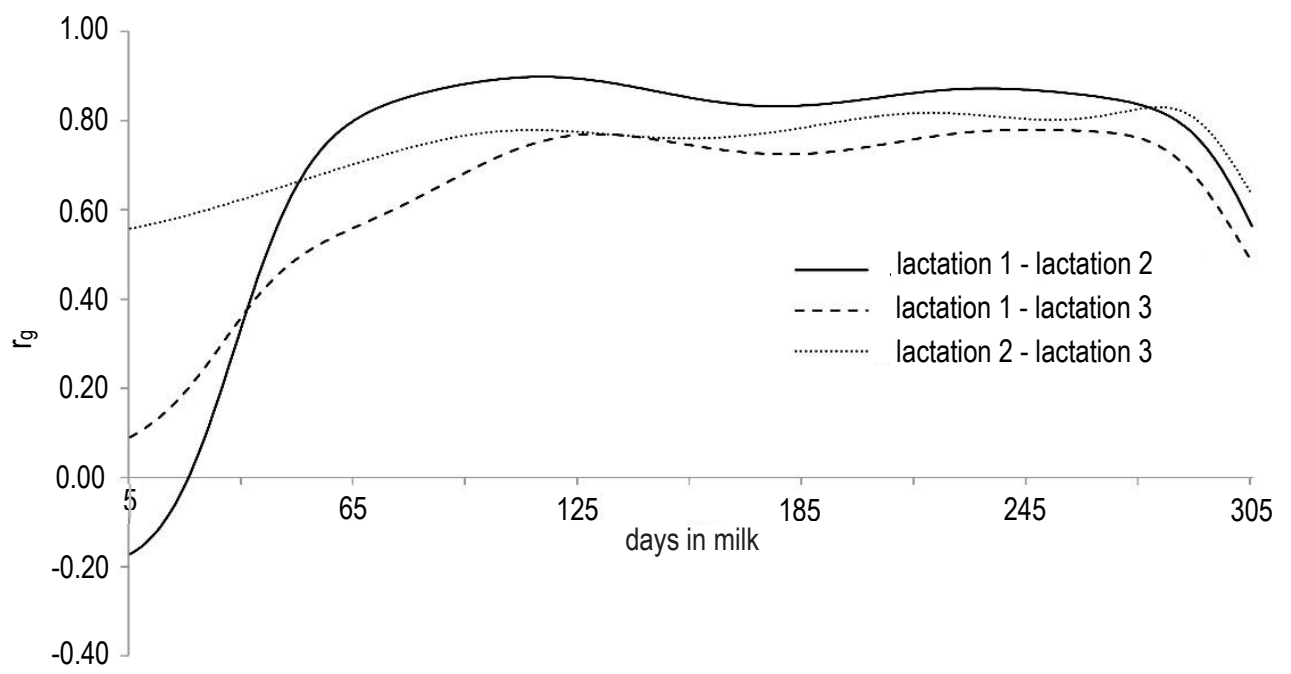

Figure 10. Genetic correlations $\left(r_{g}\right)$ between fat-to-protein ratio at the same days in milking of two of three lactations

tations and at the end of the second lactation. During the first month of lactation this relatively strong correlation between FPR and lactose content was negative in the first and third lactations whereas positive in the second.

Daily milk urea content was weakly or moderately and in most days positively genetically correlated with FPR. The values of that correlation ranged from -0.07 to $0.15,0.24$ to 0.45 and -0.07 to 0.31 in the first, second and third lactations, respectively. The genetic correlation between FPR and urea concentration was positive at every DIM only in the second lactation with a relatively high average value $(0.32)$. In the first and third lactations the mean values of correlation were close to 0 (0.03 in first and third lactations).
The genetic correlations between FPR at the same DIM of two lactations (first and second, second and third, first and third) are shown in Figure 10. All correlations were high $(0.6-0.9)$ except for those at the beginning of lactations. FPR at the same DIM in adjacent lactations was the most correlated. The average values of those correlation were 0.74 for first and second lactations and 0.75 for second and third lactations. That relationship was weaker between first and third lactations ( 0.65 on average).

\section{Discussion}

Descriptive statistics. The average daily milk yield presented in this study was higher than results reported by Buaban et al. (2016) (11.6-13.0), 
Puangdee et al. (2017) (12.7-13.7) and lower than those presented by Nishiura et al. (2015) (27.8-34.5). The FPR averages were found constant (1.15-1.16) in each of first three lactations. It was in agreement with results obtained by Buaban et al. (2016) (1.15) and Puangdee et al. (2017) (1.17-1.18). Averages of FPR presented by Nishiura et al. (2015) (1.21-1.26) and Negussie et al. (2013) (1.29) were higher. Different values of FPR and milk yield among different studies may be explained by differences in breeds, feeding and maintenance system. Generally, the optimum FPR ranges from 1.2 to 1.4 (Buaban et al., 2016). Values higher than 1.4 may indicate energy deficit and subclinical ketosis and values lower than 1.2 may suggest subclinical rumen acidosis. Enemark (2008) gave slightly different ranges of optimum FPR (1.0-1.5). Koeck et al. (2013) confirmed that FPR higher than 1.5 at the beginning of lactation (5-30 DIM) was genetically correlated with ketosis.

The average milk yield curves presented in our study are similar to those presented by other researchers (Jamrozik and Schaeffer, 2012; Negussie et al., 2013; Nishiura et al., 2015; Buaban et al., 2016; Puangdee et al., 2017). Differences among studies occurred in peak milk yield and persistency. As an example Nishiura et al. (2015) obtained slightly higher values of peak milk yield in second and third lactations of Japanese Holsteins (40 and $43 \mathrm{~kg}$, respectively) than those presented in our study. Negussie et al. (2013) who examined Finnish first-lactation cows, found lower milk yield value at peak in the first lactation $(27 \mathrm{~kg})$. Much lower values of peak milk yield in first two lactations (16 and $18 \mathrm{~kg}$, respectively) of Thai Holsteins were presented by Puangdee et al. (2017) and Buaban et al. (2016), which might be explained by completely different environmental and maintenance conditions of Thai cows (tropical climate, small dairy farms) than Polish ones. The most similar pattern throughout the first lactation was observed for milk yield of Polish (our result) and Canadian Holsteins (Jamrozik and Schaeffer, 2012).

The average FPR curves for Polish HolsteinFriesians in the first three lactations resembled in shape curves for Canadian Holsteins (Jamrozik and Schaeffer, 2012), Nordic Red Cattle in Finland (Negussie et al., 2013) and Japanese Holsteins (Nishiura et al., 2015). In those studies FPR varied during lactation with the highest values (1.26-1.45) at the beginning of lactation, then decreasing till 50-100 DIM and stabilizing afterwards. It was worth to note that FPR stabilized at different level for different population: 1.15 for Canadian (Jamrozik and Schaeffer, 2012), 1.2 for Japanese (Nishiura et al., 2015) and 1.3 for Finnish population (Negussie et al., 2013). In case of Polish Holsteins FPR stabilized about 65 DIM on the level 1.15.

Generally, in many populations of dairy cows the highest values of FPR were observed in the early phase of lactation, i.e. in the most energy deficit phase of lactation. Heuer et al. (1999) and Koeck et al. (2013) indicated that cows with FPR higher than 1.5 were more exposed to ketosis and other metabolic diseases, and caused fertility and health problems afterwards (Heuer et al., 1999; Koeck et al., 2013). Monitoring FPR in this critical stage of lactation seems to be an easy, readily available and low-cost tool to identify cows at risk of negative energy balance.

Variances. Changes of genetic, permanent environmental and residual variances of FPR throughout lactation are rarely presented. Puangdee et al. (2017) showed daily genetic variance of FPR in the first two lactations of Thai Holsteins. They observed increasing genetic variance from the beginning to 305 DIM of the first lactation, whereas in the second lactation the pattern of changes was U-shaped. Those results were opposite to those of our study (Figures 3-5). For Polish cows the values of genetic variance were the highest at the beginning of the lactation, decreased slightly up to 35 DIM, and remained constant for the remaining part of lactation (Figure 3). The higher values of genetic variance at the beginning of lactation might be connected with the lower number of observations during this period of time. It may be also explained by genetic differences in cows' ability to overcome a negative energy balance under a given feeding system.

Heritabilities. Heritability for FPR estimated in this study $(0.31,0.27,0.24$ on average in the first, second and third lactations, respectively) were in range of estimates in previous reports (Pena, 2006; Buttchereit et al., 2011; Jamrozik and Schaeffer, 2012; Loker et al., 2012; Battagin et al., 2013; Negussie et al., 2013; Nishiura et al., 2015; Buaban et al., 2016; Puangdee et al., 2017). The FPR heritability presented in the mentioned studies differ probably due to breed and feed system differences, the type of model and the effects included in it. Authors who used random regression test-day models obtained higher FPR heritability values. Lower values of heritability for FPR (0.19 and 0.11 ) were given by Pena (2006) and Battagin et al. (2013). In the work of Buttchereit et al. (2011), estimated daily heritability of FPR between 15 and 
180 DIM for German Holstein-Friesian primiparous cows ranged from 0.20 to 0.54 , the highest at the beginning of the lactation and at the end of the data recording period, and the lowest at about 100 DIM. Jamrozik and Schaeffer (2012) presented a similarly shaped heritability curve for Canadian primiparous cows. The highest value $(0.38)$ was also at the beginning of the lactation, then rapidly decreased to 0.12 at 50 DIM and increased gradually to the end of the lactation, to 0.20 at 305 DIM. Loker et al. (2012) also found high average heritability of FPR (0.42) for Canadian primiparous Holstein-Friesian cows. Negussie et al. (2013) obtained a quite differently shaped heritability curve for Nordic Red cattle in Finland. The lowest value (0.13) was at the beginning of the lactation, increasing to 0.25 (170 DIM) and stabilizing until 270 DIM, then declining slightly to 0.23 at the end. Not many FPR heritability estimates were reported for multiparous cows (Nishiura et al., 2015; Puangdee et al., 2017). Those obtained by Nishiura et al. (2015) ranged from 0.27 to 0.31 for each of the first three lactations, and were almost constant throughout the lactations, lower in mid and late stages of the third lactation. They reported that the differences in heritability estimates on particular DIM did not exceed 0.05 and occurred between the first and third lactations. In our study the differences between heritability estimates at particular DIM were much higher (up to 0.15); almost constant values of heritability at successive DIM were observed only in the third lactation, with the exception of the end of lactation. Moreover, the shapes of the heritability curves differed depending on lactation number (Figure 6). The heritability curve in the third lactation was rather a mirror image of the first lactation curve. Puangdee et al. (2017) presented differently shaped heritability curves for the first two lactations of Thai Holsteins, and showed that FPR heritability increased at successive DIM (0.11 to 0.24$)$ of the first lactation and resembled a U-shaped curve in the second lactation, with higher values at the peripheries and lower in the mid part of lactation. Their FPR heritability estimates throughout the second lactation were higher than those for the same DIM of the first lactation. This is opposite to our results as well as to those of Nishiura et al. (2015); in both studies, heritability was highest in the first lactation. One of the possible explanation of this phenomenon is that the contribution of genetic variance to total variance is the highest in the first lactation. Looking at Figures 3, 4 and 5 we observe higher values of permanent environmental variance and residual variance in second and third lactations than in first lactation whereas the values of genetic variance are almost the same for particular DIM of the first three lactations. It means that for elder cows (being in the second and third lactations) the nongenetic factors have higher impact on variability of FPR. Also Nishiura et al. (2015) observed the highest values of heritability in the first lactation for Japanese Holsteins. Spurlock et al. (2012) and Nishiura et al. (2015) mentioned that there are metabolic differences between primiparous and elder cows.

\section{Genetic correlations}

Genetic correlations between FPR and milk yield. Genetic correlations between FPR and milk yield were negative for almost all DIM of the first three lactations, and were in agreement with results of Jamrozik and Schaeffer (2012), Nishiura et al. (2015), Buaban et al. (2016) and Puangdee et al. (2017). Nishiura et al. (2015) estimated negative genetic correlations between FPR and milk yield in the first three lactations, except for early first lactation, when the genetic correlation was positive but low (up to 0.07). Their genetic correlations between FPR and milk yield decreased with increasing number of lactations, as in our study. Puangdee et al. (2017) also found a negative genetic relationship between FPR and milk yield in Thai Holsteins during the whole first lactation, and in the second lactation except for the first 65 DIM; in both lactations the daily genetic correlations gradually decreased to -0.46 and -0.52 at 305 DIM of the first and second lactations, respectively. In primiparous Canadian Holsteins, Jamrozik and Schaeffer (2012) obtained slightly positive genetic correlations (up to 0.05 ) between FPR and milk yield at the beginning of lactation; for the remaining part of lactation the correlations were negative (up to -0.4). Having data on healthy cows and cows with mastitis, they concluded that cows with mastitis were characterized by higher FPR and somatic cell score than their healthy contemporaries and suggested that FPR, which is easily available and highly heritable, potentially can be used as an indicator trait in selection against mastitis. In Thai crossbred dairy cows, Buaban et al. (2016) observed positive but small genetic correlations between FPR and milk yield (0.05) in early lactation; those correlations decreased to a minimum -0.44 at 185 DIM and then reached -0.32 at 365 DIM. They also showed that selection for lower FPR would decrease the number of inseminations per conception and increase conception at first service and pregnancy within 
90 days. They mentioned, however, that very low FPR is known to be an indicator for subclinical rumen acidosis, so the optimum value of FPR with appropriate economic weights should be included in breeding programs. Negussie et al. (2013) showed much higher, positive and significant genetic correlations between FPR and milk yield $(0.20)$ at the beginning of the first lactation. They explained that cows with high milk production have a tendency to mobilize body reserves to meet the high energy demands of peak milk yield and thus a relatively higher FPR. After the highest milk production, the genetic correlations between FPR and milk yield became close to zero or negative, which might suggest that the cows came out of the state of negative energy balance.

The average genetic correlations between FPR and milk yield presented in our study were -0.52 , -0.24 and -0.05 in the first, second and third lactations, respectively. Positive but very low values (up to 0.1 ) were estimated only in the early second lactation (until 25 DIM) and between 175 and 255 DIM of the third lactation. The genetic correlations between FPR and milk yield at the beginning of the first lactation were about -0.4 . It may suggest that improving FPR in early period of lactation, the period critical for energy deficit, should have positive effect on milk yield. In the second lactation, as was mentioned above, the genetic correlation between FPR and milk yield was positive but very low and in the third lactation oscillated around 0 , so improving FPR in the second and third lactations should have no impact on milk yield. According to results of Buttchereit et al. (2011) selection on decreasing FPR during early stage of lactation would affect not only milk yield but also milk composition, i.e. fat percentage would lower and protein percentage slightly increase.

Genetic correlations of FPR with lactose percentage and milk urea concentration. The average genetic correlation of FPR with lactose percentage was similar in magnitude and sign in the first and third lactations ( -0.08 and -0.06 , respectively), and lower than that obtained by Locker et al. (2012) for primiparous Canadian dairy cows $(-0.12)$. Considering the beginning of the lactation, the genetic correlation between FPR and lactose percentage was negative in the first and third lactations ( -0.3 and -0.4 , respectively) and increased to 0 up to 65 DIM. Selection on lower FPR in this period of lactation should result in increasing lactose percentage. In the second lactation the genetic correlations between FPR and lactose percentage at the begin- ning of lactation were oscillated around 0 , so selection on FPR in this period should have no effect on lactose percentage.

The genetic relationship between FPR and milk urea concentration (0.31) reported by Locker et al. (2012) in the first lactation was similar to our estimate in the second lactation ( 0.32 on average). The genetic correlations between FPR and milk urea concentration at the beginning of the first three lactations were positive $(0.1,0.4$ and 0.3 in first, second and third lactation, respectively). Selection on lower FPR at the beginning of lactation would result in decreasing milk urea concentration, which is desirable.

Genetic correlations for FPR at the same DIM of different lactations. The genetic correlations for FPR at the same DIM of different lactations (first and second, first and third, second and third) were high (0.6-0.9) except for the beginning of lactation, especially between the first and second lactations (Figure 10). Puangdee et al. (2017) also obtained a strong genetic relationship for FPR at the same DIM of the first two lactation (higher than 0.66). In contrast to our results, they showed the highest genetic correlations (greater than 0.83 ) for FPR between lactations before 80 DIM. Selection to improve FPR for Polish Holstein-Friesians in early stage of the first lactation, which is the most critical for energy deficit, would have a limited impact on FPR at the beginning of the second and third ones because rather low genetic correlations at the same DIM of first and second lactations and first and third lactations in that period existed.

\section{Conclusions}

Fat-to-protein ratio (FPR) is a heritable trait and could be used as an important indicator of the energy balance in order to minimize the early lactation metabolic load through selection. The genetic correlation of FPR with milk yield was negative at the beginning of the first lactation and close to 0 at the beginning of the second and third lactation, so selection for lower FPR should not have unfavourable effect on milk yield. Such selection could result in increasing lactose percentage at the beginning of lactations. Simultaneously decreasing of milk urea concentration would be expected when FPR was included into selection index. Additional research is needed to determine whether the genetic relationships between FPR and economically important traits connected with health and fertility are favourable enough to include FPR in breeding goals. 


\section{Acknowledgement}

This research was financed by the Ministry of Science and Higher Education of the Republic of Poland (DS 3254).

\section{References}

Battagin M., Sartori C., Biffani S., Penasa M., Cassandro M., 2013. Genetic parameters for body condition score, locomotion, angularity, and production traits in Italian Holstein cattle. J. Dairy Sci. 96, 5344-5351, https://doi.org/10.3168/jds.20126352

Buaban S., Duangjinda M., Suzuki M., Masuda Y., Sanpote J., Kuchida K., 2016. Genetic relationships of fertility traits with test-day milk yield and fat-to-protein ratio in tropical smallholder dairy farms. Anim. Sci. J. 87, 627-637, https:// doi.org/10.1111/asj.12472

Butler W.R., Smith R.D., 1989. Interrelationships between energy balance and postpartum reproductive function in dairy cattle. J. Dairy Sci. 72, 767-783, https://doi.org/10.3168/jds.S00220302(89)79169-4

Buttchereit N., Stamer E., Junge W., Thaller G., 2010. Evaluation of five lactation curve models fitted for fat:protein ratio of milk and daily energy balance. J. Dairy Sci. 93, 1702-1712, https://doi.org/10.3168/jds.2009-2198

Buttchereit N., Stamer E., Junge W., Thaller G., 2011. Short communication: Genetic relationships among daily energy balance, feed intake, body condition score, and fat to protein ratio of milk in dairy cows. J. Dairy Sci. 94, 1586-1591, https://doi.org/10.3168/jds.2010-3396

Collard B.L., Boettcher P.J., Dekkers J.C.M., Petitclerc D., Schaeffer L.R., 2000. Relationships between energy balance and health traits of dairy cattle in early lactation. J. Dairy Sci. 83, 2683-2690, https://doi.org/10.3168/jds.S00220302(00)75162-9

de Vries M.J., Veerkamp R.F., 2000. Energy balance of dairy cattle in relation to milk production variables and fertility. J. Dairy Sci. 83, 62-69, https://doi.org/10.3168/jds.S00220302(00)74856-9

Enemark J.M.D., 2008. The monitoring, prevention and treatment of sub-acute ruminal acidosis (SARA): A review. Vet. J. 176, 32-43, https://doi.org/10.1016/j.tvjl.2007.12.021

Falconer D.S., 1989. Introduction to Quantitative Genetics. $3^{\text {rd }}$ Edition. Longman Scientific \& Technical. London (UK)

Friggens N.C., Ridder C., Løvendahl P., 2007. On the use of milk composition measures to predict the energy balance of dairy cows. J. Dairy Sci. 90, 5453-5467, https://doi.org/10.3168/ jds.2006-821

Geishauser T., Leslie K., Tenhag K., Bashiri A., 2000. Evaluation of eight cow-side ketone tests in milk for detection of subclinical ketosis in dairy cows. J. Dairy Sci. 83, 296-299, https://doi. org/10.3168/jds.S0022-0302(00)74877-6

Goff J.P., Horst R.L., 1997. Physiological changes at parturition and their relationship to metabolic disorders. J. Dairy Sci. $\quad 80, \quad 1260-1268$, https://doi.org/10.3168/jds.S00220302(97)76055-7

Grieve D.G., Korver S., Rijpkema Y.S., Hof G., 1986. Relationship between milk composition and some nutritional parameters in early lactation. Livest. Prod. Sci. 14, 239-254, https://doi. org/10.1016/0301-6226(86)90083-7
Heuer C., Schukken Y.H., Dobbelaar P., 1999. Postpartum body condition score and results from the first test day milk as predictors of disease, fertility, yield, and culling in commercial dairy herds. J. Dairy Sci. 82, 295-304, https://doi.org/10.3168/ jds.S0022-0302(99)75236-7

Jamrozik J., Schaeffer L.R., 1997. Estimates of genetic parameters for a test day model with random regressions for yield traits of first lactation Holsteins. J. Dairy Sci. 80, 762-770, https://doi. org/10.3168/jds.S0022-0302(97)75996-4

Jamrozik J., Schaeffer L.R., 2012. Test-day somatic cell score, fat-toprotein ratio and milk yield as indicator traits for sub-clinical mastitis in dairy cattle. J. Anim. Breed. Genet. 129, 11-19, https://doi.org/10.1111/j.1439-0388.2011.00929.x

Kirkpatrick M., Hill W.G., Thompson R., 1994. Estimating the covariance structure of traits during growth and ageing, illustrated with lactation in dairy cattle. Genet. Res. 64, 5769, https://doi.org/10.1017/S0016672300032559

Koeck A., Miglior F., Jamrozik J., Kelton D.F., Schenkel F.S., 2013. Genetic associations of ketosis and displaced abomasum with milk production traits in early lactation of Canadian Holsteins. J. Dairy Sci. 96, 4688-4696, https://doi.org/10.3168/jds.20126408

Kowalski Z.M., Plyta A., Rybicka E., Jagusiak W., Sloniewski K., 2015. Novel model of monitoring of subclinical ketosis in dairy herds in Poland based on monthly milk recording and estimation of ketone bodies in milk by FTIR spectroscopy. ICAR Techn. Ser. 19, 25-30

Loker S., Bastin C., Miglior F., Sewalem A., Schaeffer L.R., Jamrozik J., Ali A., Osbornell V., 2012. Genetic and environmental relationship between body condition score and milk production traits in Canadian Holsteins. J. Dairy Sci. 95, 410-419, https://doi.org/10.3168/jds.2011-4497

McArt J.A.A., Nydam D.V., Oetzel G.R., 2012. Epidemiology of subclinical ketosis in early lactation dairy cattle. J. Dairy Sci. 95, 5056-5066, https://doi.org/10.3168/jds.2012-5443

Misztal I., 2008. Reliable computing in estimation of variance components. J. Anim. Breed. Genet. 125, 363-370, https:// doi.org/10.1111/j.1439-0388.2008.00774.x

Negussie E., Strandén I., Mäntysaari E.A., 2013. Genetic associations of test-day fat:protein ratio with milk yield, fertility, and udder health traits in Nordic Red cattle. J. Dairy Sci. 96, 1237-1250, https://doi.org/10.3168/jds.2012-5720

Nishiura A., Sasaki O., Aihara M., Takeda H., Satoh M., 2015. Genetic analysis of fat-to-protein ratio, milk yield and somatic cell score of Holstein cows in Japan in the first three lactations by using a random regression model. Anim. Sci. J. 86, 961-969, https://doi.org/10.1111/asj.12388

Oltenacu P.A., Broom D.M., 2010. The impact of genetic selection for increased milk yield on the welfare of dairy cows. Anim. Welfare 19, Suppl. 1, 39-49

Pena J., 2006. Genetic correlated traitsfor female fertility evaluation in Spanish Holstein. Interbull Bull. 34, 31-33

Piechowska T., 2015. Current state and future prospects of dairy cattle breeding in Poland (in Polish: Stan obecny i perspektywy hodowli bydła mlecznego w Polsce). Wiad. Zootechn.53, 3 , $36-45$

Puangdee S., Duangjinda M., Boonkum W., Katawatin S., Buaban S., Thepparat M., 2017. Genetic associations between milk fat-to-protein ratio, milk production and fertility in the first two lactations of Thai Holsteins dairy cattle. Anim. Sci. J. 88, 723-730, https://doi.org/10.1111/asj.12685 
Reist M., Erdin D., von Euw D. et al., 2002. Estimation of energy balance at the individual and herd level using blood and milk traits in high-yielding dairy cows. J. Dairy Sci. $\quad 85, \quad 3314-3327$,https://doi.org/10.3168/jds.S00220302(02)74420-2

Spurlock D.M., Dekkers J.C.M., Fernando R., Koltes D.A., Wolc A., 2012. Genetic parameters for energy balance, feed efficiency, and related traits in Holstein cattle. J. Dairy Sci. 95 5393-5402, https://doi.org/10.3168/jds.2012-5407
Toni F., Vincenti L., Grigoletto L., Ricci A., Schukkent Y.H., 2011. Early lactation ratio of fat and protein percentage in milk is associated with health, milk production, and survival. J. Dairy Sci. 94, 1772-1783, https://doi.org/10.3168/jds.2010-3389

Zwald N.R., Weigel K.A., Chang Y.M., Welper R.D., Clay J.S., 2004. Genetic selection for health traits using producer-recorded data. II. Genetic correlations, disease probabilities, and relationships with existing traits. J. Dairy Sci. 87, 4295-4302, https://doi.org/10.3168/jds.S0022-0302(04)73574-2 